В. Б. Гриців, кандидат педагогічних наук, доцент (Львівський науково-навчальний інститут ДВНЗ "Університет банківської справи") Vitaliya.hrytsiv@gmail.com ORCID : $0000-0001-7424-0363$

\title{
ПІДВИЩЕННЯ ПЕДАГОГІЧНОЇ МАЙСТЕРНОСТІ НАУКОВО-ПЕДАГОГІЧНОГО СКЛАДУ ВИЩОГО НАВЧАЛЬНОГО ЗАКЛАДУ ЯК ПЕРЕДУМОВА ДО ФОРМУВАННЯ ПРОФЕСІЙНО- ЕТИЧНОӤ КОМПЕТЕНТНОСТІ МАЙБУТНЬОГО ФАХІВЦЯ БАНКІВСЬКОӤ СПРАВИ
}

У даній статті розглянуто особливості та проаналізовано основні складові педагогічної майстерності до формування професійно-етичної компетентності майбутнього фахівия банківської справи.

Визначено передумови підвищення рівня педагогічної майстерності науково-педагогічного складу вищого навчального закладу. 3 викладених у статті суджень стосовно досліджуваної проблеми, окреслено ряд важливих рекомендаиій.

Ключові слова: педагогічна майстерність, професійно-етична компетентність, науково-педагогічний склад, фахівець банківської справи.

Постановка проблеми. У світлі соціально-економічних перетворень, що відбуваються в українській державі, на перший план у сфері професійної освіти виходять проблеми підготовки фахівців, здатних, передусім, аналізувати нестандартні ситуації, приймати оптимальні рішення в умовах невизначеності та прогнозувати можливі наслідки. На сьогодні ці завдання актуалізуються, оскільки виникає необхідність пошуку нових шляхів підвищення ефективності підготовки фахівців банківської справи. Однією 3 передумов вирішення важливого і складного завдання з підготовки конкурентоздатних фахівців $\epsilon$ розвиток педагогічної майстерності науково-педагогічного складу навчального закладу, зокрема, шляхом покращання психолого-педагогічної підготовки майбутніх викладачів та формування їх готовності до професійного самовдосконалення, саморозвитку, а через нього - продуктивної педагогічної діяльності.

Аналіз останніх досліджень і публікацій. Дослідженню педагогічної майстерності викладачів вищих навчальних закладів присвячені праці С. П. Архипової, І. А. Зязюна, П. Г. Лузан, С. Г. Погорілої, О. А. Столярчука, В. М. Теслюка, Є. В. Тягнирядно, Л. М. Шовкун та інших. Проте в їх працях мова здебільшого йде про загальні питання професійної майстерності викладача в умовах звичайного навчального процесу. Підвищення педагогічної майстерності науково-педагогічного складу вищого навчального закладу як один із аспектів формування професійно-етичної компетентності сучасного фахівця банківської справи ще не була предметом дослідження.

Метою статті $є$ проаналізувати основні складові педагогічної майстерності науково-педагогічного складу вищого навчального закладу до формування професійно-етичної компетентності сучасного фахівця банківської справи та вказати на деякі шляхи її вдосконалення.

Виклад основного матеріалу. Актуальність проблеми викликана необхідністю врахування нових вимог до вищої освіти в умовах трансформації суспільства, фінансового простору та потребою компетентних фахівців банківської справи.

Педагогічну майстерність прийнято трактувати як сукупність якостей особистості, які забезпечують високий рівень самоорганізації професійної діяльності педагога. Складовими педагогічної майстерності називають професійні знання, педагогічну техніку, педагогічні здібності, педагогічну моральність, професійно значущі якості та зовнішню культуру [1: 57]. Нам імпонує думка А. Маркової, яка вважає, що в основі педагогічної майстерності лежить високий рівень професіоналізму. Загалом це своєрідний сплав особистої культури, знань і світогляду педагога, його всебічної теоретичної підготовки 3 досконалим володінням прийомами навчання і виховання, педагогічного технікою і передовим досвідом.

Слід зазначити, що формування професійно-етичної компетентності майбутніх фахівців банківської справи висуває специфічні вимоги до особистісних якостей викладача, його моральних ціннісних орієнтацій та якостей. Окрім необхідних кожному викладачеві загальнокультурних та спеціальних знань, принципового значення набувають знання основ етики бізнесу, професійної етики банківського працівника, правил організації конструктивних комунікацій, а також основ конфліктології.

Важливо, щоб такий педагог усвідомлював, що він виховує людину, відповідальну за долю інших людей, людину, яка, працюючи з великими потоками грошей, повинна уміти утримуватись від заздрості, жадібності та матеріальних спокус. У цьому випадку сам викладач, як зазначає І. Бех, повинен мати спрямованість на цінність служіння і виховувати іiі у своїх студентів. Для цього важливо, на думку I. Беха, щоб викладач розумів, що "спрямованість виховного процесу на цінність служіння заперечує цілковиту орієнтацію на цінність соціальних досягнень і володіння. За активної цінності соціальних досягнень як визначальної основним ставленням до життя стає суперництво, що створює тривожні настрої, невпевненість у собі й виступає перепоною для успішного особистісного розвитку. За цінності 
володіння людина є тільки об’єктом, засобом для досягнення цілей, моральних заборон тут немає" [2: 39].

Викладачеві для формування професійно-етичної компетентності майбутніх працівників банківської сфери необхідні також певні якості, важливі для розуміння молодих людей. Це, насамперед:

здатність сприймати й адекватно психологічно інтерпретувати поведінку молодої людини безпосередньо в кожний момент спілкування, фіксувати зміни в почуттях і вчинках, визначати причини, які ці зміни зумовлюють;

сформованість широкого набору оцінних критеріїв, які б давали йому змогу порівняти характер змін, що настають у вербальній і невербальній поведінці молодих людей, і своєчасно робити щодо цього правильні висновки;

уміння постійно усвідомлювати і правильно реагувати на те, як сприймають і психологічно інтерпретують його образ і поведінку студенти;

знання про типові помилки ("стереотипізація", "нав’язування суб’єктивного бачення" тощо), що їх нерідко допускають педагоги при оцінці зовнішнього внутрішнього образу студентів, а також при психологічному поясненні їхньої поведінки [2: 44].

Слід зазначити, що при формуванні у студентської молоді суспільно значущих моральних якостей як основних у структурі їх особистості домінантна роль належить спілкуванню. Серед різних стилів спілкування - діалогічного, альтруїстичного, конформістського, пасивного, маніпулятивного, авторитарно-монологічного, конфліктного - Г. Васянович для формування у студентів необхідних моральних якостей пропонує дотримуватись, насамперед, діалогічного. На думку дослідника, основними ознаками діалогічного стилю є активність, контактність і висока ефективність спілкування; педагогічний оптимізм, опора на позитивний потенціал особистості студента; поєднання доброзичливої вимогливості 3 довірою до молодої людини; впевнена відкритість, щирість і природність у спілкуванні; безкорислива чуйність і емоційне прийняття студентів як партнерів по спілкуванню, прагнення до взаєморозуміння i співпраці; достатньо висока та адекватна самооцінка, розвинене почуття гумору [3: 235].

Діалогічний стиль спілкування є вищим рівнем організації педагогічного процесу і притаманного йому розвивального, виховного і творчого потенціалу. Він забезпечує необхідний моральнопсихологічний контакт, який має виникати між учасниками педагогічного процесу і перетворювати їх на суб'єктів спілкування. Такий стиль дозволяє долати різноманітні психологічні бар'єри при взаємодії викладача зі студентами (вікові, соціально-психологічні, мотиваційні, пізнавальні, ціннісні тощо), трансформує традиційну для молодих людей позицію підкорення, підпорядкування на позицію співпраці та перетворює їх на суб’єктів власної діяльності [3: 237].

Учений I. Бех вважає, що психологічно повноцінне спілкування можна досягти, дотримуючись таких умов:

- взаємодія партнерів "на рівних" (рівність сутнісних позицій учасників спілкування, або суб'єктсуб'єктні відносини), коли постійно робиться поправка на своєрідність один одного і не дозволяється принижувати гідність один одного;

- довірлива взаємна відкритість обох сторін;

- відсутність оцінювального, "вимірювального"ставлення до будь-яких сторін індивідуальності кожного;

- взаємне прийняття один одного як неповторних і цінних особистостей [2: 100].

Для організації роботи 3 формування професійно-етичної компетентності у майбутніх фахівців банківської справи представникам науково-педагогічного складу необхідно постійно звертати увагу на підвищення своєї педагогічної майстерності, здійснювати творчу оптимізацію як професійного, так i особистісного потенціалу. Загалом аналіз наукових джерел дозволяє визначити такі основні передумови підвищення рівня педагогічної майстерності науково-педагогічного складу вищого навчального закладу до формування професійно-етичної компетентності сучасного фахівця банківської справи:

- орієнтація на професійно-етичні цінності та їх дотримання;

- володіння необхідними академічними знаннями (педагогічними, психологічними та фаховими) на високому рівні;

- високий рівень застосування професійних засобів праці (інноваційних технологій, технік, прийомів, методів), систематична підготовка до занять;

- високий рівень розвитку професійного мислення;

- прийнятний індивідуальний стиль професійної діяльності;

- систематичне поповнення фахових знань, постійний науковий пошук, вдосконалення.

Отже, для формування професійно-етичної компетентності майбутніх фахівців банківської сфери важливе значення має підвищення педагогічної майстерності науково-викладацького складу. Особистість викладача - це важливий фактор, що визначає результативність формування професійно-етичної компетентності у майбутніх фахівців банківської справи. Професійна майстерність викладача ВНЗ належить до феноменальних педагогічних явищ, яке приходить з досвідом, знаннями, роздумами, 
дотриманням методичних вимог та порад. Важливою умовою підвищення рівня професійної майстерності викладача $є$ усвідомлення ним, прийняття та розуміння сучасних вимог до професійної діяльності, знання специфіки роботи 3 формування моральних якостей та професійно-етичної компетентності, уміння налагоджувати недирективну особистісно-орієнтовану взаємодію та діалог із студентами.

У цьому контексті ми проаналізували практичну діяльності науково-педагогічного складу ДВНЗ "Університет банківської справи", який засвідчив певні труднощі викладачів у роботі з формування у студентів професійно-етичної компетентності. Виявлено, що насамперед викладачі потребують більше інформації щодо особливості організації роботи у цьому напрямі. 3 огляду на це, для підвищення рівня професійної майстерності науково-педагогічного складу важливо організувати наступне:

- відвідування занять представників науково-педагогічного складу, які мають статус кращих методистів;

- відвідування міжнародних, загальноукраїнських конференцій, тематика яких пов’язана 3 професійною майстерністю, професійно-етичною культурою тощо;

- взаємовідвідування різних видів занять (лекційних, практичних, семінарських тощо) 3 метою набуття викладачами необхідного досвіду;

- методичні наради, семінари, круглі столи, основними завданнями яких було б підвищення рівня професійної майстерності;

- вивчення досвіду представників науково-педагогічного складу у ВНЗ за допомогою різних джерел інформації.

На нашу думку, для подолання труднощів, які виникають у процесі навчання, особливого значення слід надати тематичному семінару "Актуальні питання формування професійно-етичної компетентності у майбутніх фахівців банківської справи". На цьому семінарі можна передбачити і надати викладачам інформацію щодо важливих аспектів організації роботи з формування у майбутніх фахівців банківської справи професійно-етичної компетентності.

На семінарі викладачі можуть ознайомитися 3 сутністю професійної етики як прикладної галузі філософської науки етики, структурою професійної етики, співвідношенням понять "етика", "мораль", "моральність" у діяльності банківських працівників. Особливого значення слід надати питанням про організацію роботи 3 формування у студентів професійно-етичної компетентності, специфіку використання активних методів навчання.

При цьому необхідно враховувати, що ефективність роботи 3 формування професійно-етичної компетентності у майбутніх фахівців банківської справи залежить від професіоналізму викладача, його теоретичної підготовки, практичного досвіду, від його морального прикладу та авторитету.

Педагог повинен бути для студентів прикладом, зразком для наслідування у вирішенні проблем морального характеру. Особливе значення у цьому контексті має характер взаємодії викладачів та студентів, тип їхнього спілкування. Викладачі намагаються прищепити студентам уявлення про важливість тривалої та повсякденної праці, про працю як істинний вияв справжньої цінності людини. Ключовою при цьому, на наш погляд, є думка В. Сухомлинського про те, що "активний вплив думок і моральних почуттів - це поєднання найрізноманітніших видів діяльності. Крім фізичної праці, велике виховне значення має колективна діяльність, яка вимагає подолання труднощів суто морального характеру. Завдання вчителя-вихователя полягає в тому, щоб спонукати учня до такої праці, в основі якої лежить цікавий творчий задум. Поєднання інтелектуальних і фізичних зусиль у такій праці і $є$ умовою духовного загартування молодого покоління, умовою формування його готовності до продуктивної праці" [4: 232].

При організації взаємодії зі студентами необхідно надавати перевагу такому типу взаємин, як співпраця, при якій викладачі використовують не директивний вплив, а переконуючий, намагаючись обгрунтувати свої думки, рішення, пояснити студентам суть своїх вимог і своїх дій. Викладачі у роботі зі студентами повинні показати їм приклад відповідного ціннісного ставлення налагодження міжособистісної взаємодії, насамперед щодо ставлення один до одного не як до засобу вирішення своїх проблем, а як до гідних поваги співрозмовників. Педагогам слід переконати студентів у важливості та пріоритетності дотримання моральних норм в особистому та професійному житті - 3 огляду не на тактичні, а стратегічні цілі: гідного і чесного виконання професійного обов'язку.

Діалогічний спосіб навчання має охоплювати як спільний пошук педагогами та студентами шляхів розв'язання складних завдань морально-етичного характеру, так і стимулювання самостійності студентів у професійно-етичному вдосконаленні. Відповідно до поради В. Сухомлинського, одне 3 основних завдань морального виховання викладачі вбачали у тому, щоб "дбайливо оберігати, зміцнювати в душах юнаків та дівчат благородне почуття їхньої духовної правоти у великому і малому, відкривати перед ними можливості для випробування сумління" [4: 384].

Висновки. На підставі теоретичного аналізу та практичного досвіду можна зробити висновок, що для формування професійно-етичної компетентності у майбутніх фахівців банківської справи представникам 
науково-педагогічного складу необхідно постійно звертати увагу на підвищення своєї педагогічної майстерності, здійснювати творчу оптимізацію як професійного, так і особистісного потенціалу. Для цього важливе значення має орієнтація на професійно-етичні цінності та їх дотримання; володіння необхідними академічними знаннями (педагогічними, психологічними та фаховими); високий рівень застосування професійних засобів праці (інноваційних технологій, технік, прийомів, методів), систематична підготовка до занять; відповідний індивідуальний стиль професійної діяльності; систематичне поповнення фахових знань, постійний науковий пошук, вдосконалення та ін.

Перспективами подальших розвідок у даному напрямку є дослідження потреб у кваліфікованих фахівцях банківської справи та можливості до підвищення їх конкурентоздатності на сучасному ринку праці, а також вивчення міжнародного досвіду підготовки кваліфікованих кадрів.

\section{СПИСОК ВИКОРИСТАНИХ ДЖЕРЕЛ ТА ЛІТЕРАТУРИ}

1. Фіцула М. М. Педагогіка вищої школи : [навч. посіб.] / М. М. Фіцула. - К. : Академвидав, 2006. - 352 с. (Альма-матер).

2. Бех І. Д. Виховання особистості. У 2 кн. Кн. 2. Особистісно орієнтований підхід : теоретико-технологічні засади / І. Д. Бех. - К. : Либідь, 2003. - 344 с.

3. Васянович Г. П. Педагогічна етика : [навч. посіб.] / Г. П. Васянович. - К. : Акадевидав, 2011. - 256 с. (Серія "Альма-матер").

4. Сухомлинський В. О. Проблеми виховання всебічно розвиненої особистості / В. О. Сухомлинський // Вибр. твори : в 5 т. К. : Рад. шк, 1976. - Т. 1.-654 с.

5. Маркова А. К. Психология профессионализма / А. К. Маркова. - М. : Просвещение, 1996. - 312 с.

\section{REFERENCES (TRANSLATED \& TRANSLITERATED)}

1. Fitsula M. M. Pedahohika vyshchoi shkoly [Pedagogics of Higher School] : [navchal'nyi posibnyk] / M. M. Fitsula . - K. : Akademvydav, 2006. - 352 s. - (Al'ma-mater).

2. Bekh. I. D. Vykhovannia osobystosti. U 2 kn. Kn. 2. Osobystisno orientovanyi pidkhid : teoretyko-tekhnolohichni zasady [Pesonality Development Training. In 2 Books. Book 2. Personally Oriented Approach: Theoretical and Technological Principles] / I. D. Bekh. - K. : Lybid', 2003. - 344 s.

3. Vasianovych H. P. Pedahodichna etyka [Pedagogical Ethics ] : [navch. posibnyk] / H. P. Vasianovych. - K. : Akademvydav, 2011. - 256 s. - ("Al'ma-mater series").

4. Sukhomlynskyi V.O. Problemy vykhovannia vsebichno rozvynenoi osobystosti [Problems of Education of a Fully Developed Personality] / V. O. Sukhomlynskyi // Vybr. tvory : v 5 t. [Selected Works : in 5 Volumes]. - K. : Rad. Shk, 1976. - T. 1. $-654 \mathrm{~s}$.

5. Markova A. K. Psiholohiia profesionalizma [Psychology of Professionalism] / A. K. Markova. - M. : Prosvishchenie, 1996. -312 s.

Грыцив В. Б. Повышение педагогического мастерства профессорско-преподавательского состава вуза как предпосылка к формированию профессионально-этической компетентности будущего специалиста банковского дела.

В данной статье рассмотрены особенности и проанализированы основные составляюшие педагогического мастерства к формированию профессионально-этической компетентности будущего специалиста банковского дела. Определены предпосылки повышения уровня педагогического мастерства профессорско-преподавательского состава вуза. Из изложенных в статье суждений относительно исследуемой проблемы, нами были обозначены ряд важных рекомендаций.

Ключевые слова: педагогическое мастерство, профессионально-этическая компетентность, научнопедагогический состав, специилист банковского дела.

\section{Hrytsiv V. B. Enhancement of Pedagogical Skill of Scientific and Pedagogical Staff of a Higher Educational Institution as a Prerequisite for the Formation of the Professional and Ethical Competence of a Future Specialist of Banking.}

An important precondition for training of competitive banking sector specialists is development of teaching skills of the scientific and pedagogical staff of an educational institution. The article deals with the peculiarities and the main components of pedagogical skills for the formation of the professional and ethical competence of a future banking specialist. In the basis of pedagogical skill there must be a high level of professionalism. In general, it is a kind of amalgamation of personal culture, knowledge and outlook of the teacher, his / her comprehensive theoretical training along with being good at methods of teaching and applying pedagogical techniques and advanced experience.

The following methods were used in the research: analysis, generalization, systematization of the scientific source data with the intention of defining the ways to enhance the level of pedagogical skills in order to form the professional and ethical competence of the bankers-to be. 
As a result of the research some recommendations have been worked out. The author singles out the importance of holding workshops, seminars, meetings for improving teaching skills and as a matter of fact for enhancing student outcomes. Representatives of the scientific and pedagogical staff must constantly pay attention to improving their pedagogical skills in order to optimize professional as well personal potential.

Key words: pedagogical skill, scientific and pedagogical staff, professional and ethical competence. 